\title{
Observation of a tropopause fold by MARA VHF wind-profiler radar and ozonesonde at Wasa, Antarctica: comparison with ECMWF analysis and a WRF model simulation
}

\author{
M. Mihalikova ${ }^{1,2}$, S. Kirkwood ${ }^{1,2}$, J. Arnault ${ }^{1}$, and D. Mikhaylova ${ }^{1}$ \\ ${ }^{1}$ Polar Atmospheric Research, Swedish Institute of Space Physics, Box 812, 98128, Kiruna, Sweden \\ ${ }^{2}$ Division of Space Technology, Luleå University of Technology, Kiruna, Sweden \\ Correspondence to: M. Mihalikova (maria.mihalikova@irf.se)
}

Received: 27 June 2012 - Revised: 4 September 2012 - Accepted: 5 September 2012 - Published: 28 September 2012

\begin{abstract}
Tropopause folds are one of the mechanisms of stratosphere-troposphere exchange, which can bring ozone rich stratospheric air to low altitudes in the extra-tropical regions. They have been widely studied at northern mid- or high latitudes, but so far almost no studies have been made at mid- or high southern latitudes. The Moveable Atmospheric Radar for Antarctica (MARA), a $54.5 \mathrm{MHz}$ wind-profiler radar, has operated at the Swedish summer station Wasa, Antarctica $\left(73^{\circ} \mathrm{S}, 13.5^{\circ} \mathrm{W}\right)$ during austral summer seasons from 2007 to 2011 and has observed on several occasions signatures similar to those caused by tropopause folds at comparable Arctic latitudes. Here a case study is presented of one of these events when an ozonesonde successfully sampled the fold. Analysis from European Center for Medium Range Weather Forecasting (ECMWF) is used to study the circumstances surrounding the event, and as boundary conditions for a mesoscale simulation using the Weather Research and Forecasting (WRF) model. The fold is well resolved by the WRF simulation, and occurs on the poleward side of the polar jet stream. However, MARA resolves fine-scale layering associated with the fold better than the WRF simulation.
\end{abstract}

Keywords. Meteorology and atmospheric dynamics (Mesoscale meteorology; Polar meteorology; Instruments and techniques)

\section{Introduction}

Ozone in the atmosphere plays an important role in both the stratosphere and troposphere. It is perhaps best known for its role in the stratosphere where it absorbs UV radiation, thus protecting the biosphere from harmful radiation. Other important aspects of ozone's role in the atmosphere include, for example, heating of the stratosphere by UV absorption, making the stratosphere strongly statically stable and inhibiting mixing between the stratosphere and troposphere. Ozone in surface air is well known as a toxic pollutant but it also acts as a short-lived greenhouse gas and, together with water vapour, it plays an important role in controlling the lifetime of many other tropospheric trace gases. Ozone in the troposphere is also an important tracer of transport, both downward transport from the stratosphere and horizontal transport of air from areas affected by biomass burning or industrial pollution (Randriambelo et al., 2000). Long-range transport, which can be traced with the help of ozone measurements, influences not only the local atmospheric air quality, but, in the case of polar regions, also the climate record stored in the ice in terms of many other trace gases and their isotopic composition (see e.g. Helsen et al., 2007).

Globally, the main source of ozone $\left(\mathrm{O}_{3}\right)$ in the troposphere is photochemistry within the troposphere, both naturally occurring and due to pollution. However, for understanding long-term development and budgets of $\mathrm{O}_{3}$ in the troposphere, the stratospheric source is important, particularly where or when the atmosphere is not strongly affected by modern industrial sources or biomass burning. For example, the model study (based on ECMWF global data sets) by Lelieveld and Dentener (2000), suggested that 40-60\%

Published by Copernicus Publications on behalf of the European Geosciences Union. 
of tropospheric ozone in pre-industrial times came from the stratosphere, with similar contributions estimated even for present day conditions for remote Southern-Hemisphere locations such as Antarctica. More recently, Sudo and Akimoto (2007) used a tagged tracer method in a global chemical climate model to estimate that $23 \%$ of tropospheric ozone comes from the stratosphere. The troposphere in polar regions is, however, to a large extent statically stable and not well mixed in the vertical direction. As a result, most of the stratospheric $\mathrm{O}_{3}$ is found in the upper troposphere. For example, according to the modelling study by Sudo and Akimoto (2007), for the high-Arctic site of Resolute Bay, as much as $75 \%$ of ozone at $300 \mathrm{hPa}$ (in spring) has a stratospheric origin, but less than $20 \%$ at $800 \mathrm{hPa}$. Studies of transport into the Arctic (Stohl, 2006) and into coastal Antarctica (Stohl and Sodemann, 2010) using a Lagrangian particle dispersion model have concluded that less than $0.5 \%$ could be traced to the stratosphere within the 10-day tracing interval. Slightly higher values, up to $2 \%$ were found for the high-altitude region of the Antarctic Plateau. On the other hand, an analysis of observed seasonal variations in surface ozone, combined with modelling using an atmospheric chemistry GCM (Tarasova et al., 2007) concluded that about $55 \%$ of surface ozone at polar sites (including Barrow, Alaska, Neumayer and Syowa in costal Antarctica) comes from the stratosphere. So, although a stratospheric influence on the tropospheric column as a whole is generally agreed, there is less consensus regarding the relative contribution of stratospheric ozone to surface ozone concentrations in the polar regions.

Air is transported from the stratosphere to the troposphere (and vice-versa) through a variety of processes known as stratosphere-troposphere exchange (STE). Tropopause folds have been identified as a likely major source of STE (Shapiro, 1980; Holton et al., 1995) outside the tropics. These are synoptic-scale intrusions of tongues of air with stratospheric characteristics (high $\mathrm{O}_{3}$, low humidity and high potential vorticity, PV) which are forced down into the troposphere at boundaries between warmer and colder air masses in the upper troposphere, close to the sub-tropical and polar jets. Analysis of global meteorological data by Sprenger et al. (2003), Sprenger and Wernli (2003) found that STE due to tropopause folds was indeed important in the subtropics, but it seemed that folds were too rare at higher latitudes to make a significant contribution. Erosion of cut-off low systems and breakup of stratospheric streamers were instead proposed as possible sources of STE in the extratropics. Further studies, again using global meteorological data (Sprenger et al., 2007) confirmed a link between STE, streamers and cut-off lows at mid and high northern latitudes, although the link was less clear for the highest latitudes, i.e. the Arctic.

A number of studies of STE have been made based on direct observations, and fine-scale modelling, at high northern (including Arctic) latitudes. Stratospheric intrusions have been detected for example by in-situ measurements (using ozonesondes or aircraft) as layers of air with higher ozone mixing ratios and lower humidity in the troposphere (Van Haver et al., 1996; Beuermann et al., 2002; Dibb et al., 2003; Rao and Kirkwood, 2005; Semane et al., 2007). These show that intrusions of stratospheric air (tropopause folds), down to heights as low as $2 \mathrm{~km}$, occur at high northern latitudes, but they are not resolved by the usual detection methods based on global meteorological databases. Assimilation of satellite limb measurements has been proposed as one way to improve detectability of such stratospheric intrusions using global meteorological databases (Semane et al., 2007). A new global real-time Lagrangian diagnostic system for STE has been developed by Bourqui et al. (2012) and first tests, using comparison with a campaign of daily ozonesonde launches in Eastern Canada, showed an unexpectedly high number of observed stratospheric intrusions with stratospheric air below $500 \mathrm{hPa}(700 \mathrm{hPa})$ found in $79 \%$ $(38 \%)$ of profiles.

VHF wind-profiler radars have also proved to be useful tools for tropopause fold studies, with some radars offering the possibility of long series of observations so that climatologies can be made. This is due to a close relation between radar reflectivity and static stability (e.g. Vaughan et al., 1995; Hooper et al., 2004). Folds can be readily observed in radar data as high level frontal zones (sloping layers of high radar reflectivity) descending from the tropopause into the middle troposphere, or lower. They are generally accompanied by a change in the height of the tropopause (also readily identified as a boundary with high reflectivity) suddenly increasing by hundreds of meters (up to $3 \mathrm{~km}$ in individual cases). Often a change in the wind direction near the frontal zone and frontal circulation in the vertical velocity can also be detected by the radar. For example, VHF radars have been used to study folds at mid- to high latitudes over Britain by Vaughan et al. (1994); Reid and Vaughan (2004), and over Eastern Canada by Hocking et al. (2007). At Arctic latitudes $\left(68^{\circ} \mathrm{N}\right.$ in Sweden) they have been studied using radar by Rao and Kirkwood (2005) and Rao et al. (2008). By making comparisons with ECMWF analysis, Rao et al. (2008) found that folds detected by the radar were generally associated with streamers or cutoff lows. Since the radar had operated continuously over many years they were also able to study the climatology of the folds. They found that the occurrence rate was substantially higher (5-10\%) than expected according to the analysis of global meterological data by Sprenger et al. (2003) (0-2\%), suggesting that there may in practise be many unresolved tropopause folds associated with the cutoff lows and streamers found using global meteorological databases.

Although there are many observational and fine-scale modelling studies of STE and tropopause folds at high northern and Arctic latitudes, very little has been published concerning high southern or Antarctic latitudes. To our knowledge, the only published study for the region south of $45^{\circ} \mathrm{S}$ is by Baray et al. (2012). This is based on ozonesondes launched from Kerguelen Island $\left(49^{\circ} \mathrm{S}\right)$ and fine-scale 
Lagrangian trajectory tracking. Evidence was found for intrusion of stratospheric air close to the jet stream (tropopause fold) down to the $550 \mathrm{hPa}$ level.

In 2007, a new, small VHF wind profiler radar, MARA (Kirkwood et al., 2007) was deployed in Queen Maud Land, Antarctic $\left(73^{\circ} \mathrm{S}, 13.5^{\circ} \mathrm{W}\right)$. Although operations were restricted to a few weeks each summer season, it was soon apparent that very similar structures to those identified as tropopause folds by VHF radar at Arctic latitudes, were also seen over the Antarctic site. Since the ECMWF-based study of Sprenger et al. (2003) found no evidence for folds over this location during the summer months, this was somewhat surprising. As complementary in-situ measurements are preferable to properly identify folds, ozonesondes were launched at the radar site in subsequent summer seasons when the radar indicated fold-like signatures. In this paper we present a first case study of a tropopause fold observed by MARA, with co-located ozonesonde measurements and a comparison with the way in which the situation can be represented by ECMWF (European Centre for Medium-Range Weather Forecasts) synoptic data and by a mesoscale model constrained by ECMWF analysis, the WRF (Weather Research Forecast) model (Skamarock and Klemp, 2008).

\section{Instruments and data}

\subsection{Radar and sonde observations}

MARA (Movable Atmospheric Radar for Antarctica) is an interferometric $54.5 \mathrm{MHz}$ wind profiler radar. It was installed and operated at the Swedish/Finnish summer stations WASA/Aboa in Queen Maud Land $\left(73^{\circ} \mathrm{S}, 13.5^{\circ} \mathrm{W}\right)$ in the austral summer season of 2006/2007 (Kirkwood et al., 2007) and during 3 summer seasons until the season 2010/2011. (After this season MARA was moved to its present location at the Norwegian station Troll $72^{\circ} \mathrm{S}, 2.5^{\circ} \mathrm{E}$ and is in operation year-round.) The measurements considered here were made in the season 2010/2011. The quantities measured are profiles of echo power plus Doppler shift, auto and cross correlations at and between 3 receivers, each connected to a separate antenna sub-array. Signal-to-noise ratio (SNR) and buoyancy frequency are derived from the echo power and horizontal wind speeds are calculated using full correlation technique and the cross-correlations between the 3 receivers (Holdsworth and Reid, 1995). Vertical wind speed is determined from the doppler shift but is not used in the present study. Turbulence estimates (velocity variations in the vertical direction) can also be found using the full correlation technique but high SNR is needed for useful accuracy. Buoyancy frequency is calculated for easier direct comparison with the profile of static stability from model data. This is possible since, for vertically pointing radars operating around $50 \mathrm{MHz}$, the echo power returned from the upper troposphere and lower stratosphere is predominantly determined by the

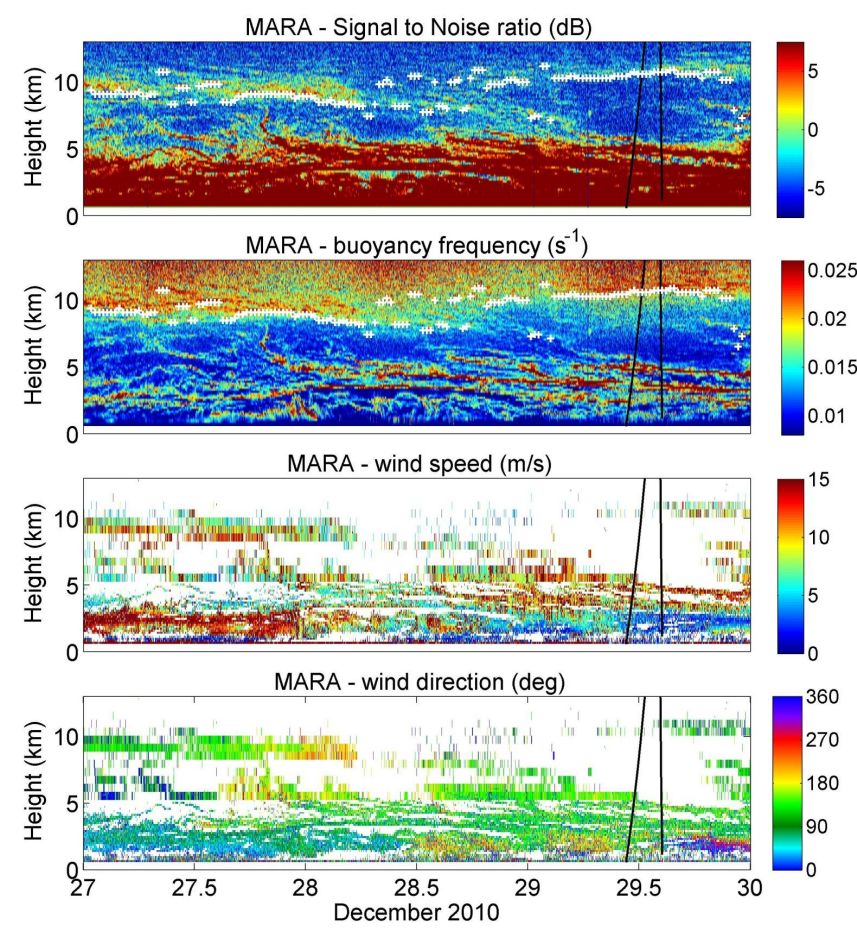

Fig. 1. MARA radar observations of signal to noise ratio $(\mathrm{dB})$, buoyancy frequency $\left(\mathrm{s}^{-1}\right)$, wind speed $(\mathrm{m} / \mathrm{s})$ and wind direction (deg) from 27 December 2010 to 29 December 2010. Nearly vertical black lines represent the time of ascent and descent of the ozonesonde.

mean temperature gradients (with allowance for the distance from which it is returned and the scale height of atmospheric density). Echo power can thus be scaled to provide an estimate of static stability:

$R_{\mathrm{B}}^{2}=F_{e} z \exp (z / H) P_{\mathrm{r}}^{1 / 2}$,

where $P_{\mathrm{r}}$ is radar echo power, $z$ is height and $H$ is atmospheric scale height or time. $F_{e}$ is constant of proportionality, independent of height. In the case where humidity is or can be assumed to be negligible, as in the upper troposphere and lower stratosphere, $R_{\mathrm{B}}$ provides a good estimate of buoyancy frequency (Kirkwood et al., 2010, or for further details Hooper et al., 2004). The constant of proportionality, $F_{e}$, in this case was found by comparison with ozonesonde measurements made on 29 December (the sonde measurements are described in more detail in the Sect. 5).

During the 2010/2011 season MARA was running in two operating modes summarized in Table 1 . The two modes were operated in alternate minutes, with fca_150 providing good height resolution $(150 \mathrm{~m})$ but relatively low SNR while fca_4500 has poorer height resolution $(600 \mathrm{~m})$ but higher SNR. MARA observations for a 3-day period in December 2010 are shown in Fig. 1, where fca_150 forms the basis of the measurements shown for SNR and buoyancy frequency at all heights, and wind speed and direction below $5 \mathrm{~km}$ altitude. 
Table 1. MARA: technical details and radar operating modes for the summer season 2010/2011.

\begin{tabular}{lll}
\hline Location & $73.04^{\circ} \mathrm{S}, 13.41^{\circ} \mathrm{W}$ & \\
Altitude & $470 \mathrm{~m}$ a.s.l. & \\
Frequency & $54.5 \mathrm{MHz}$ & \\
Max. duty cycle & $7.5 \%$ & \\
Peak power & $20 \mathrm{~kW}$ & \\
No. of receivers: & 3 & fca_4500 \\
Operating modes season 2010/2011 & fca_150 & $600 \mathrm{~m}$ \\
Sampling resolution & $150 \mathrm{~m}$ & 8-bit complementary \\
Code & 4-bit complementary & \\
Further information: & http://www.irf.se/link/MARA_AFP_IRF & \\
Online data: & http://www.irf.se//program/paf/?link=Data & \\
\hline
\end{tabular}

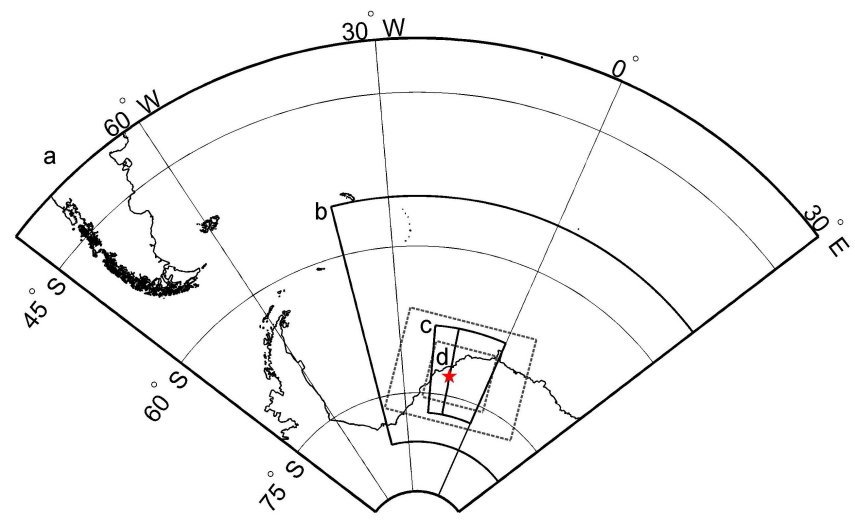

Fig. 2. Map grids used in this paper. Outer frame (a) used for the synoptic overview (Fig. 3), (b) ECMWF operational analysis tropopause maps (Fig. 4 - a), (c) WRF model tropopause maps (Fig. $4-$ b) (d) vertical cross-sections along the $13.5^{\circ} \mathrm{W}$ longitude (Fig. 5). Red star - position of MARA radar. Dashed lines represent the outer and inner domains used in WRF model simulation.

Above $5 \mathrm{~km}$, SNR becomes much lower and wind estimates are from fca_4500, although even with the higher SNR provided by this mode, there are still large gaps due to low SNR.

In the two uppermost panels of Fig. 1, we show SNR and static stability (buoyancy frequency) derived from the MARA measurements. The white crosses mark the position of the radar-derived tropopause. This has been found by first making 90-min averages of the buoyancy frequency profiles, and then looking for the maximum vertical gradient (evaluated over a $450 \mathrm{~m}$ interval) between $6 \mathrm{~km}$ and $11.6 \mathrm{~km}$ altitudes. Here a change of the tropopause height can be seen from around $9.5 \mathrm{~km}$ late on the 27 December, descending to approximately $7 \mathrm{~km}$ height on the morning of the 28th after which a multiple or indistinct tropopause starts to be observed for a while, then rising to approximately $10.5 \mathrm{~km}$ by noon on 29 December. The suspected tropopause fold is seen as thin layers of enhanced SNR/higher static stability descending from the tropopause height starting in the afternoon of the 28th. In fact, part of this fold-like structure, just after midnight on the 29th is mis-identified as the tropopause by the gradient-searching algorithm. The change of tropopause height, and the descending layer, are very similar to tropopause fold signatures identified at Arctic latitudes (Rao and Kirkwood, 2005).

\subsection{ECMWF and WRF models}

For further analysis of the situation observed by MARA, ECMWF deterministic operational model analysis data was used and the observed tropopause fold was also modelled by the WRF model with high spatial and time resolutions.

The ECMWF operational analysis was investigated for the period between 27 December 2010 and 30 December 2010, at tropospheric and lower stratospheric heights. This data is available with a horizontal resolution of approximately $16 \mathrm{~km}$ (0.125 degrees) and 4 times per day (each $6 \mathrm{~h})$. For the purpose of this case study, we looked at the data on pressure, isentropic and potential vorticity levels. To show the development at the level of the dynamical tropopause, we use tropopause maps, here based on the -2 pvu level $\left(1 \mathrm{pvu}=10^{-6} \mathrm{~K} \mathrm{~m}^{2} \mathrm{~kg}^{-1} \mathrm{~s}^{-1}\right.$, the negative value being used because of the location in the Southern Hemisphere) (Holton et al., 1995).

The WRF numerical experiment presented here consists of two, two-way nested, polar stereographic domains at horizontal resolutions 6 and $2 \mathrm{~km}$ (Fig. 2, dashed lines), with 95 vertical levels up to $20 \mathrm{hPa}$ (approximately $25 \mathrm{~km}$ ). The vertical spacing is stretched from $60 \mathrm{~m}$ to $350 \mathrm{~m}$ at the lowest and highest level, respectively. Rayleigh damping in the uppermost $5 \mathrm{~km}$ was introduced in order to avoid spurious wave reflection from the model lid (following Durran and Klemp, 1983). The terrain elevation of the inner model is specified by the data from the Radarsat Antarctic Mapping (RAM) Project Digital Elevation (PDE) Model Version 2, originally at $1 \mathrm{~km}$ resolution (Liu et al., 2001). The numerical experiment starts one day before the period of interest on 26 December 2010 at 00:00 UTC and is run for 4 days. It is coupled with ECMWF operational analysis at the initial time and every $6 \mathrm{~h}$ at the boundaries of the outer domain. The model equations are integrated in the outer and inner domains at time steps of $24 \mathrm{~s}$ and $8 \mathrm{~s}$, respectively. The inner 

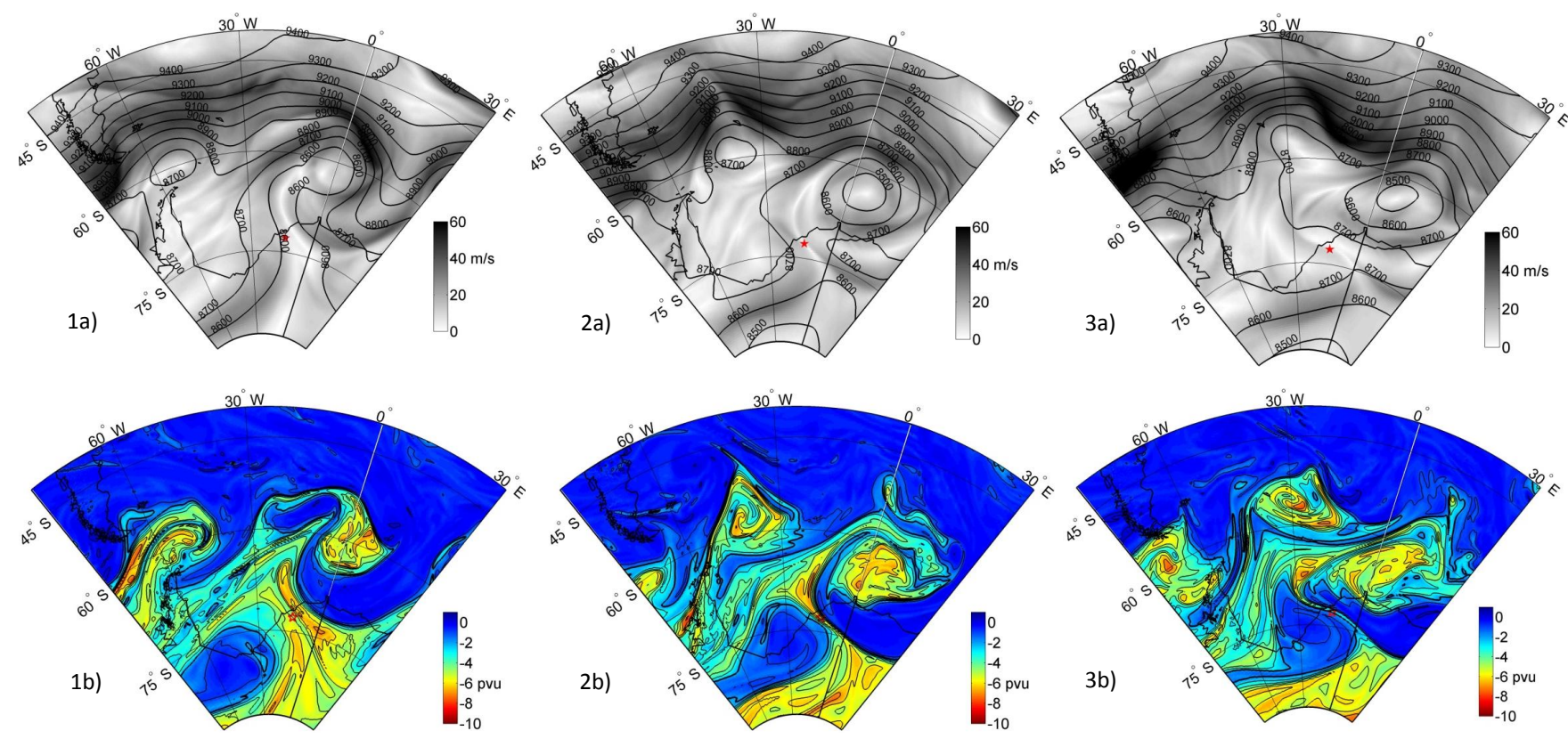

Fig. 3. ECMWF operational analysis based geopotential height (gpm) and wind speed $\left(\mathrm{m} \mathrm{s}^{-1}\right)$ at $300 \mathrm{hPa}$ level (1a, 2a, 3a) and potential vorticity (pvu) (thick line -2 pvu value) at $315 \mathrm{~K}$ isentropic level (1b, 2b, 3b) on 28 December 2010 06:00 UTC (1a, 1b), 29 December 2010, 00:00 UTC (2a, 2b) and 29 December, 12:00 UTC (3a, 3b). Map grid used as seen in Fig. 2a. Red star marks position of MARA radar.

model outputs containing the usual dynamic and thermodynamic variables are then saved every ten minutes. Convection is explicit in the inner and outer domains and microphysics is parameterized with the 3-class liquid and ice hydrometeors scheme of Hong et al. (2004). Radiative processes are represented with the long and shortwave radiation schemes of Mlawer et al. (1997) and Dudhia (1989), respectively. Subsurface heat conduction was calculated with a scheme based on a 5-layer snow temperature, and the turbulent transport of heat, moisture, and momentum was parameterized in the whole atmospheric column with the scheme of Hong et al. (2006).

Outputs from the ECMWF and WRF models are displayed for the map sections shown in Fig. 2, where the red star denotes the position of MARA. Section Fig. 2a is used for the synoptic overview (Fig. 3). Figure $2 b$ is used to show ECMWF tropopause maps (Fig. 4 - 1a, 2a, 3a) and Fig. 2c is the map section for WRF tropopause maps (Fig. $4-1 \mathrm{~b}$, 2b, 3b). Vertical cross-sections (Fig. 5) from both models are shown along the $13.5^{\circ} \mathrm{W}$ longitude (Fig. $2 \mathrm{~d}$ ). Model outputs for the synoptic situation, tropopause and vertical crosssection maps are shown for the following times: 28 December 2010, 06:00 UTC (at the beginning of the tropopause fold observation with MARA), 29 December 2010, 00:00 UTC (in the middle of the tropopause fold observation by MARA) and 29 December 2010, 12:00 UTC (at the time of the ozonesonde ascent). The figures are discussed in more detail in the following sections.

\section{Synoptic overview}

On the 27 December 2010, a low pressure system was located at the surface to the north of MARA (not shown here), moving slowly to the east. The low pressure system was deepening and was connected with a trough of low pressure from the south with wind jets on its north and eastern flanks, visible on the $300 \mathrm{hPa}$ level (Fig. 3 - 1a). Subsequently, the lowpressure system advanced to the east and formed a high level low pressure system to the northeast of MARA (Fig. 3 - 2a). During 29 December 2010, a weak ridge of high pressure extending from the northwest formed over the MARA location (Fig. 3 - 3a). Throughout this time a streamer of high potential vorticity is visible above the MARA location on the $315 \mathrm{~K}$ isentropic level (Fig. $3-1 \mathrm{~b}-3 \mathrm{~b}$ ). The thicker black line in this figure marks the -2 pvu contour. This value represents borders of air-mass with stratospheric properties. The development of the streamer into a filamentary structure during the analysed period can be seen on Fig. $3-1 b, 2 b$ and $3 b$.

\section{Tropopause fold characteristics: model and radar}

The horizontal and vertical structure of the observed fold as seen by ECMWF analysis and WRF ( $6 \mathrm{~km}$ domain) model is shown in the subsequent figures. In Fig. 4 we show tropopause maps at the times 28 December, 06:00 UTC (Fig. 4 - 1), 29 December, 00:00 UTC (Fig. 4 - 2) and 29 December, 12:00 UTC (Fig. $4-3$ ) based on the ECMWF model (Fig. $4-$ a) and WRF model (Fig. $4-$ b). The tropopause 

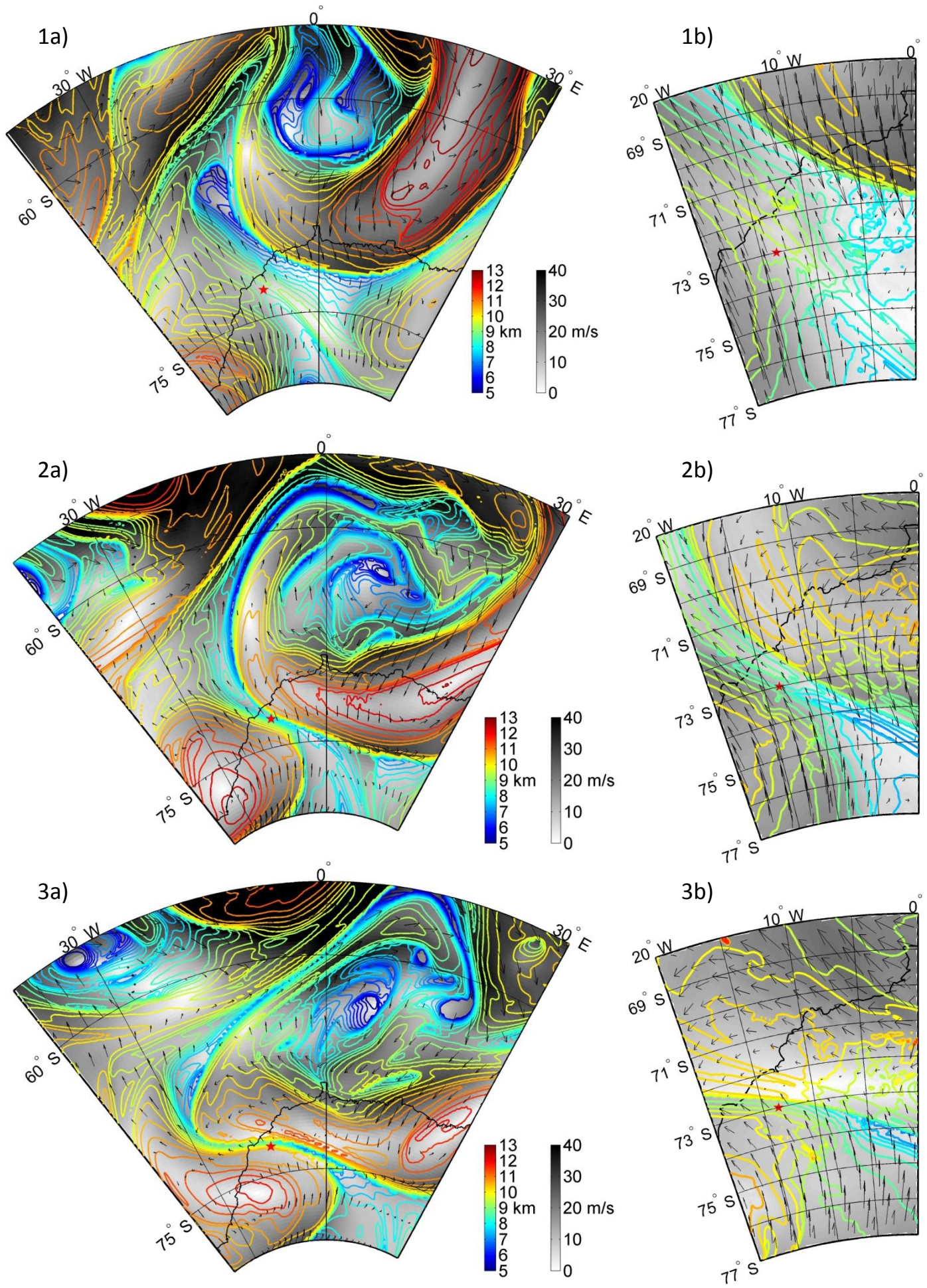

Fig. 4. Tropopause maps - height $(\mathrm{km})$, wind speed $\left(\mathrm{m} \mathrm{s}^{-1}\right)$ and wind direction at the dynamic tropopause $(-2$ pvu level of potential vorticity) from 28 December 2010, 06:00 UTC (1), 29 December 2010, 00:00 UTC (2) and 29 December 2010, 12:00 UTC (3) from ECMWF operational analysis (a) and WRF model (b). Map grids used are as seen in Fig. 2b-ECMWF model and Fig. 2c - WRF model. Red star position of MARA radar. 
1a)

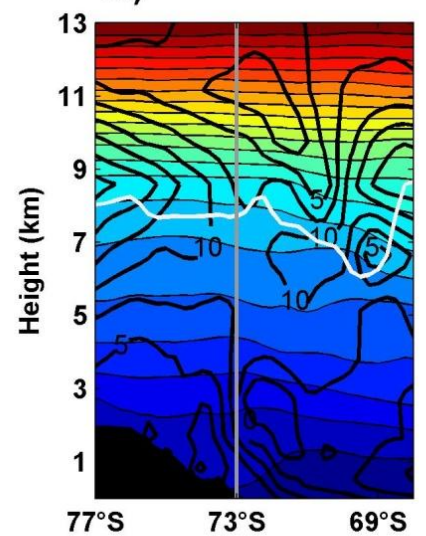

2a)

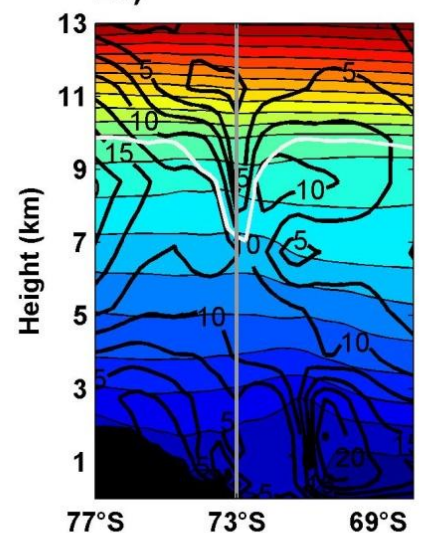

3a)
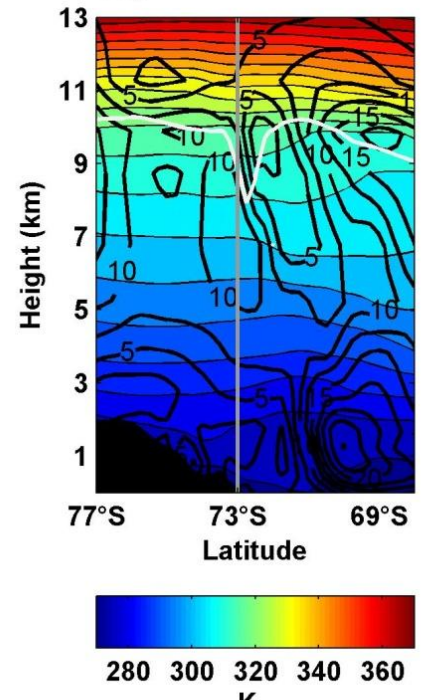

1b)

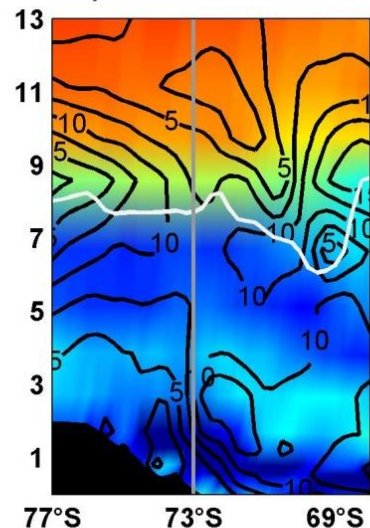

2b)

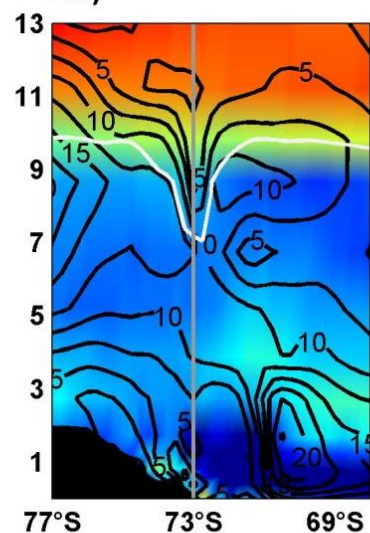

3b)
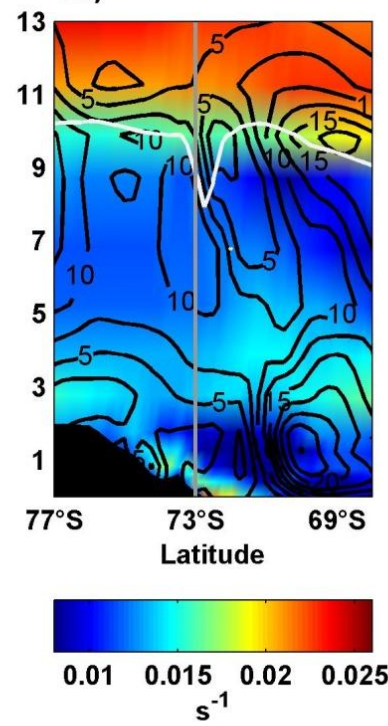

1c)

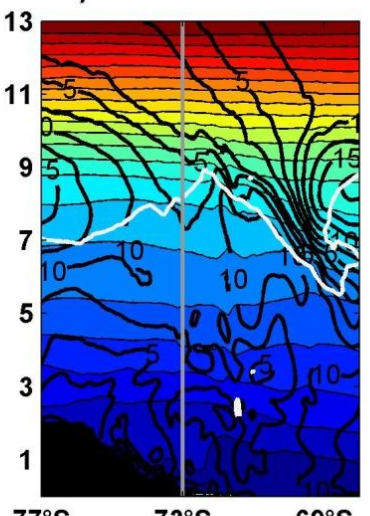

2c)

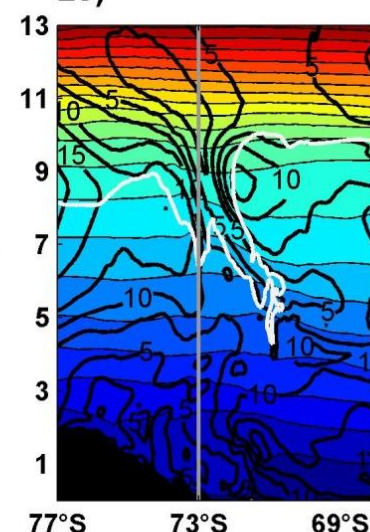

3c)
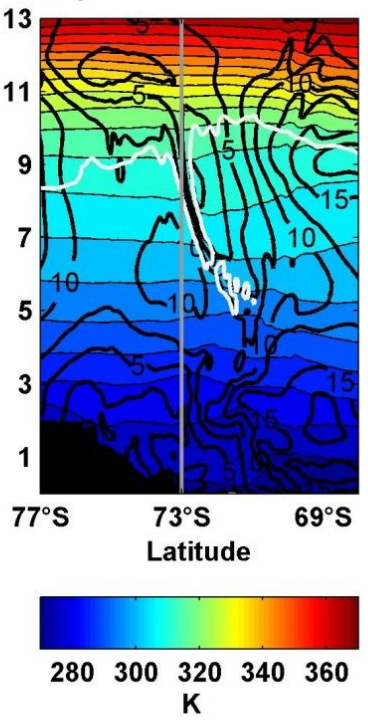

1d)

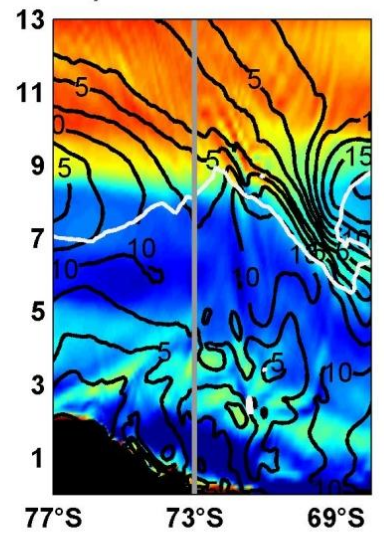

2d)

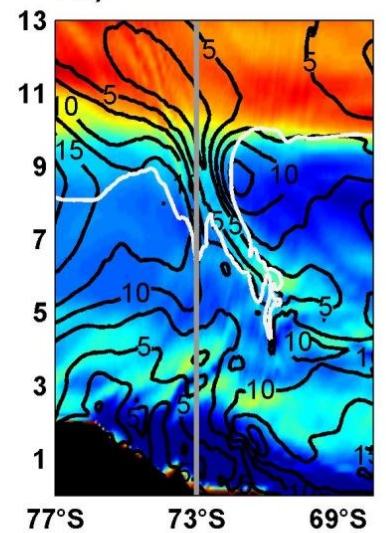

3d)
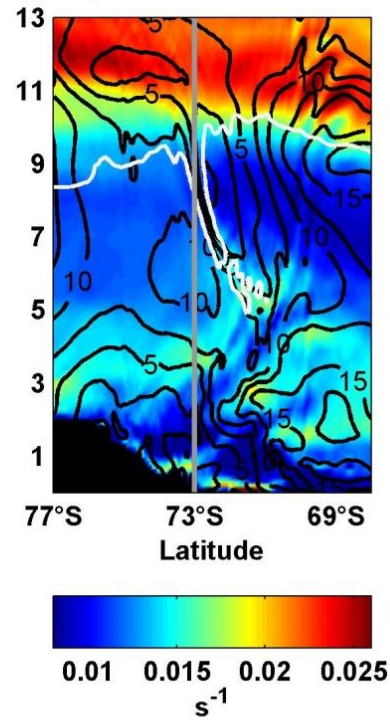

Fig. 5. Vertical cross-sections along $13.5^{\circ} \mathrm{W}$ (Fig. 2d). From 28 December 2010, 06:00 UTC (1), 29 December 2010, 00:00 UTC (2) and 29 December 2010, 12:00 UTC (3) ECMWF model (a, b) and WRF model (c, d). White line in all pictures represents the -2 pvu level of potential vorticity, vertical grey line is the location of MARA measurements, black lines show wind speed isotachs $\left(\mathrm{m} \mathrm{s}^{-1}\right)$, colour bar scales in panels (a) and (c) show the potential temperature $(\mathrm{K})$ and panels (b) and (d) buoyancy frequency $\left(\mathrm{s}^{-1}\right)$. WRF data are from the domain with $6 \mathrm{~km}$ horizontal and $3 \mathrm{~h}$ time resolutions. 

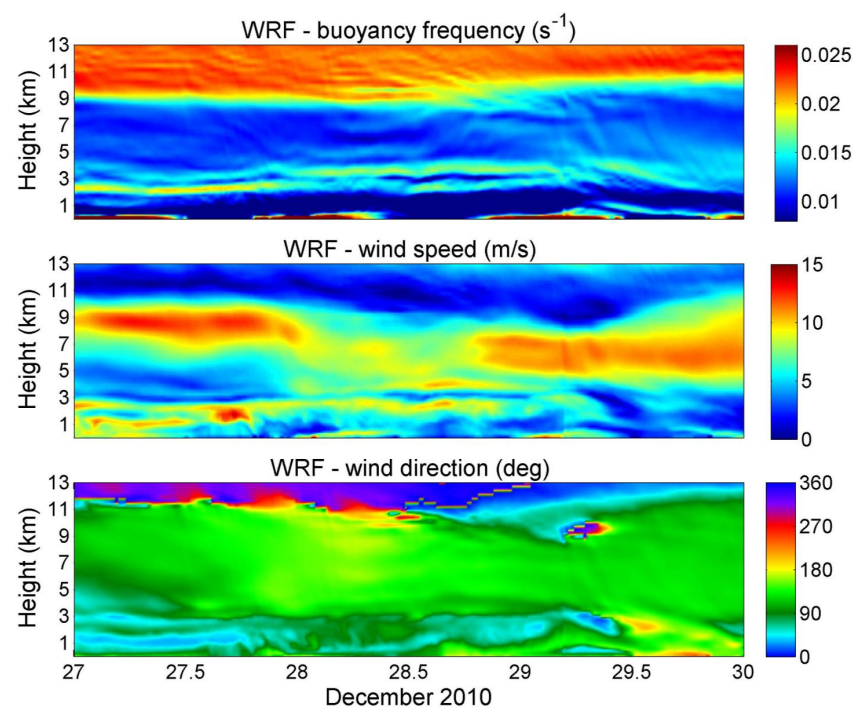

Fig. 6. Time development of buoyancy frequency $(N)$ (top), wind speed $\left(\mathrm{m} \mathrm{s}^{-1}\right)$ (middle) and wind direction (deg) (bottom) at the MARA location from the WRF inner domain with $2 \mathrm{~km}$ horizontal and output data with 10 min time resolution.

maps show the topography of the dynamical tropopause and wind speed and direction at this level. In Fig. 4 - 1a, 2a, and $3 \mathrm{a}$ we can see a strong depression in tropopause height approaching the site of MARA (red star). The dynamical tropopause height changes from $9 \mathrm{~km}$ through around $7.5 \mathrm{~km}$ to $10.5 \mathrm{~km}$. Lower heights of the tropopause are observed on the flank of a jet stream visible in the wind data. The WRF model provides tropopause maps in a smaller area with higher resolution (Fig. $4-1 b, 2 b$, and 3b). They reveal a complicated structure of the dynamical tropopause surface.

The vertical structure, development and movement of the fold in the model data can be seen in the vertical crosssections along the longitude $13.5^{\circ} \mathrm{W}$ in Fig. 5. This shows cross-sections of potential temperature (Fig. 5 - a ECMWF, Fig. 5 - c WRF), buoyancy frequency (Fig. 5 - b ECMWF, Fig. $5-d$ WRF) and wind speed (represented by the isotachs in all subfigures of Fig. 5). The dynamical tropopause is represented by a -2 pvu level isoline (white line) and the position of the MARA measurements is marked with a grey vertical line. A fold structure, approaching the MARA location from the equatorward direction, is clearly seen in the -2 pvu contour for the WRF model simulations, but appears only as a depression in the height of this contour in the ECMWF data. Changes in the spacing of isentropic levels between stratosphere and troposphere and in the fold are visible as is the higher buoyancy frequency (higher static stability) in the fold. The fold is positioned on the poleward flank of a weak jet stream which is more visible in the WRF model data, than in the ECMWF data. It is also clear that the jet weakens as the fold approaches the MARA location. The WRF model with its higher resolution shows the fold structure in detail, with descent of the dynamical tropopause to rather low height (around $5.5 \mathrm{~km}$ ), supporting the interpretation of the structure seen by MARA as related to a tropopause fold. It is significant, though, that according to the WRF simulation, the fold does not pass over the radar site toward the pole.

For a more detailed comparison of radar and model data, the time development of buoyancy frequency and wind at the MARA location from the 2-km resolution, innermost domain of WRF model is shown in Fig. 6. In the top panel, we show buoyancy frequency inferred from WRF data with a time resolution of $10 \mathrm{~min}$. The two lower panels show corresponding wind speed and direction from WRF. The buoyancy frequency exhibits very good agreement with the corresponding MARA observations (Fig. 1), although the layers in the troposphere are sharper in MARA data. In WRF data, we can see essentially the same behaviour of the tropopause height (the boundary between low and high buoyancy frequency) as with MARA. There are weak layers of higher static stability descending into the troposphere at the same time as the suspected fold structure seen by MARA. WRF even observes the same signature of gravity waves in the lower stratosphere as in MARA (on 27 December). There is also reasonable agreement between the WRF winds and those estimated by MARA, although the large gaps in coverage for MARA do not allow a comprehensive comparison. At the time of the ozonesonde launch on 29 December (marked by the black lines in Fig. 1), WRF and MARA agree on the height of the sharp increase in windspeed (at about $3 \mathrm{~km}$ ) although the wind directions below this height are rather different. On the basis of this comparison there is no reason to question the accuracy of the WRF model in representing the characteristics of the fold. For a further check, we next consider the measurements by the ozonesonde.

\section{Tropopause fold characteristics: ozonesonde}

An ozonesonde was launched on 29 December 2010 at 11:00 UTC, providing measurements of temperature, humidity and ozone concentration. This used a standard Meteolabor SRS-C34 sonde with an ECC ozone sensor. Near-vertical black lines in Fig. 1 represent the time of ascent and descent of the ozonesonde. The sonde measurements are shown in detail in Fig. 7b-d, where a cross-section through the fold from the WRF model is also shown (Fig. 7a). The positions of the ascent and descent path of the sonde are shown by red and green lines, respectively, on the cross-section. Contact with the sonde was lost for a few minutes during ascent, as it travelled between $9.5 \mathrm{~km}$ and $12 \mathrm{~km}$ height. Temperature and wind measurements covering this gap are available from the descent, but not ozone. First we can note that the thermal tropopause (at $10.5 \mathrm{~km}$ on descent) agrees well with the sharp increase in static stability in the WRF model and in MARA data. Several sharp layers/ledges of air with higher ozone concentrations and lower humidity can be seen in the 
a)

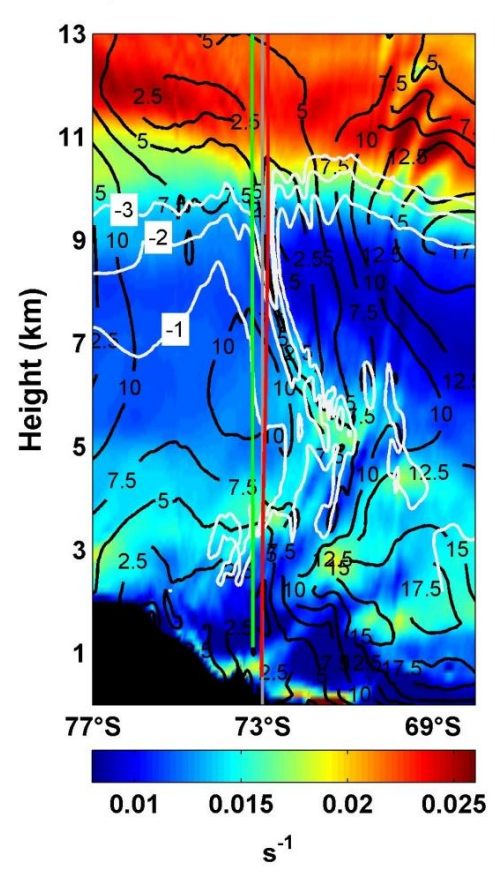

b)

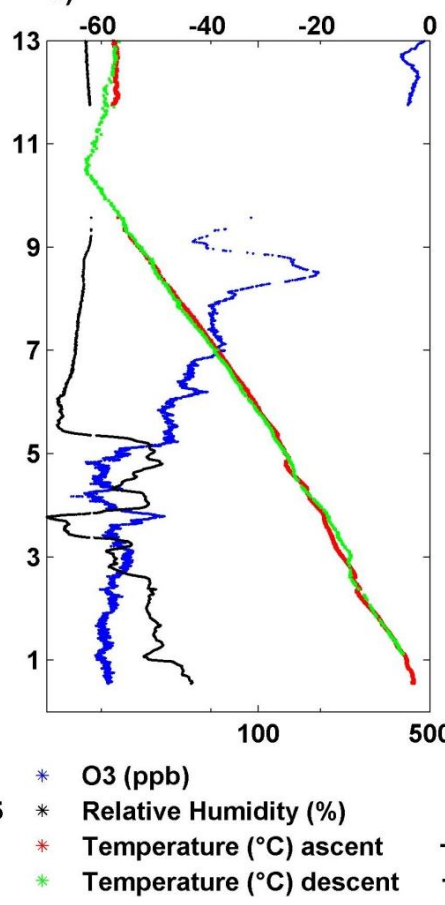

c)

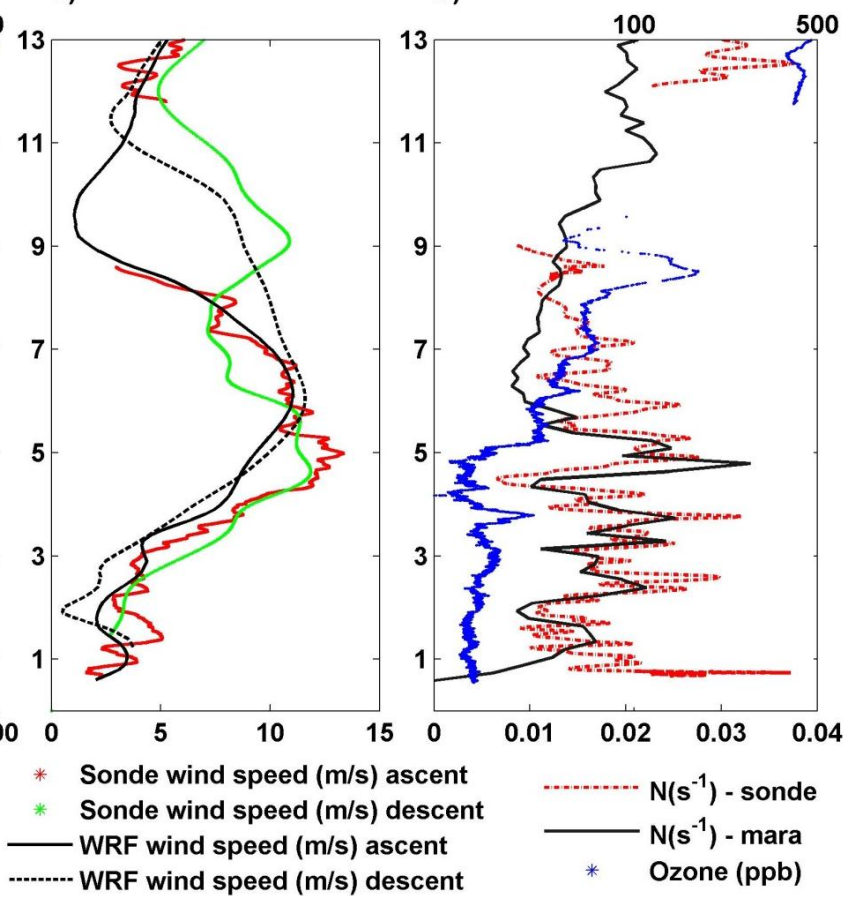

Fig. 7. Comparison of WRF cross-section with ozonesonde observations. (a) WRF cross-section of buoyancy frequency ( $\mathrm{s}^{-1}$ ) and wind speeds $\left(\mathrm{m} \mathrm{s}^{-1}\right)$ along $13.5^{\circ} \mathrm{W} .-1 \mathrm{pvu},-2 \mathrm{pvu}$ and $-3 \mathrm{pvu}$ isolines are shown in white, vertical grey line represents MARA position, red line sonde ascent and green line sonde descent positions at 12:00 UTC on 29 December 2011. (b) Sonde measurements of relative humidity $\left(\%\right.$, black), $\mathrm{O}_{3}$ mixing ratio (ppb, blue) and temperature $\left({ }^{\circ} \mathrm{C}\right.$, red - ascent, green - descent). (c) Sonde measurements of wind speed ( $\mathrm{m} \mathrm{s}^{-1}$, red - ascent, green - descent) and WRF model wind speed $\left(\mathrm{m} \mathrm{s}^{-1}\right.$, full line - ascent, dashed line - descent). (d) Comparison of $\mathrm{O}_{3}$ mixing ratio (ppb, blue) and buoyancy frequency $\left(\mathrm{s}^{-1}\right.$ ) from sonde ascent (red dashed line) and MARA (full line) data. Due to loss of contact with the sonde between $9.5 \mathrm{~km}$ and $12 \mathrm{~km}$ height, the ascent data exhibits a gap in measurements. Temperature and wind measurements covering this gap are available from the descent, but not ozone or relative humidity.

lower troposphere, around $3.5 \mathrm{~km}, 4 \mathrm{~km}$ and $5 \mathrm{~km}$. Above $6 \mathrm{~km}$ the humidity is low and the sonde measurement unreliable, but we can see that ozone concentration rises slowly up to $8 \mathrm{~km}$, then peaks before falling back at $9 \mathrm{~km}$. Finally, once the sonde is in the stratosphere above $12 \mathrm{~km}$ ozone concentrations are high. Fig. $7 \mathrm{~d}$ compares the layering in ozone and humidity with buoyancy frequency estimated by the sonde and by MARA. It is clear that, up to $6 \mathrm{~km}$ height, the sonde and MARA see the same stable layers and two of them, at $3.5 \mathrm{~km}$ and $5 \mathrm{~km}$, are associated with layers of enhanced ozone. The largest peak in ozone density (at $8.5 \mathrm{~km}$ ), coincides with a small peak in static stability according to the sonde, although nothing is obvious at the height in MARA results. This may be due to the very narrow (in latitude) scale of the fold so that it is not exactly coincident with the MARA profile.

Wind profiles from the sonde are compared with the WRF model results in Fig. 7c. Here we see the contrast in wind speed around $9 \mathrm{~km}$ height between ascent and descent paths, in both WRF and sonde data, nicely confirming that the sonde sampled exactly at the position in the fold structure suggested by the WRF model, i.e. on ascent, just crossing to the equatorward side above $8 \mathrm{~km}$, on descent, always just on the poleward side. Comparing the ozone enhancements seen by the sonde (Fig. 7b) with the PV contours estimated by WRF (Fig. 7a) we can see that the highest ozone peak (at $8.5 \mathrm{~km}$ ) corresponds to $\mathrm{PV}<-3 \mathrm{pvu}$, and the ledge at $5 \mathrm{~km}$ and the peak at $3.5 \mathrm{~km}$ correspond to crossings into regions with $\mathrm{PV}<-1 \mathrm{pvu}$. So the enhanced ozone at this level may not have come directly from the stratosphere, but perhaps from the extratropical transition layer (see e.g. Gettelman et al., 2011).

\section{Summary and conclusions}

A tropopause fold reaching the location $73^{\circ} \mathrm{S}, 13.5^{\circ} \mathrm{W}$ in Antarctica was observed by the MARA VHF wind-profiling radar between 27 and 29 December 2010. On 29 December 2010 additional measurements were made by a balloonborne Meteolabor ozone sonde with ECC sensor and vertical profiles of temperature, relative humidity, ozone mixing ratio, wind speed and wind direction were measured at 11:00 UTC. The observations have been compared with each other, and with the behaviour of the dynamical tropopause 
as seen in ECMWF operational model analysis and highresolution WRF model data.

Comparison of the radar and ozonesonde measurements, with the WRF model using two-way nested grids with an outer domain with resolution $6 \mathrm{~km}$ and an inner domain with resolution $2 \mathrm{~km}$ and with 3-h time resolution, shows that this model configuration is adequate to show the development of a tropopause fold and track its location. With the inner domain close to the radar site ( $2 \mathrm{~km}$ resolution) with 10 -min time resolution, WRF captures details in layered structures in buoyancy frequency as seen by MARA, although they are not as sharp in height. The fold approached the location of the radar from the north, and just reached the radar site. The ozonesonde made its ascent starting on the poleward side then crossed to the equatorward side of the fold, but descended entirely on the poleward side. During ascent, the ozonesonde detected layers or ledges of enhanced ozone, enhanced static stability and lower humidity at $3.5 \mathrm{~km}$ and $5 \mathrm{~km}$ heights. These correspond to levels in the WRF model where the potential vorticity fell below $-1 \mathrm{pvu}$. A stronger layer of enhanced ozone was detected at $8.5 \mathrm{~km}$ altitude with a weak signature in static stability, corresponding to $\mathrm{PV}<-3 \mathrm{pvu}$ in the WRF model. The ozone-rich layer at $3.5 \mathrm{~km}$ and the ledge at $5 \mathrm{~km}$ coincide with layers of high static stability seen in the MARA data (Fig. 1), which can be followed backwards in time up to tropopause heights. This suggests that they are indeed intrusions of stratospheric air or of air with mixed stratospheric and tropospheric characteristics from the extratropical transition layer. The lower layer, however, lies very close (in MARA observations) to a layer that remains at low height, below $4 \mathrm{~km}$, throughout the period of observation. Back-trajectories (not shown) show that air at these heights comes from close to the surface in the interior of Antarctica. Since ozone production can occur near the ice surface in summer (Helmig et al., 2008), we cannot rule out the possibility that this source contributes.

From comparison of MARA, WRF and ozonesonde results with the ECMWF analysis, we can conclude that, even though ECMWF operational analysis recognizes a folded structure of the dynamical tropopause, this is shallow and does not give a correct impression of the deep penetration of stratospheric air into the tropopause.

It seems that MARA measurements and the WRF model will be useful tools for further studies of the behaviour, characteristics or climatology of tropopause folds in coastal Antarctica. At a similar latitude in the Arctic, radar measurements have shown that tropopause folds are most frequent in the winter season (Rao et al., 2008), being present on up to $10 \%$ of winter days. Presently, MARA is stationed at the Norwegian year round station Troll $\left(72^{\circ} \mathrm{S}, 2^{\circ} \mathrm{E}\right)$ measuring also during the Antarctic winter season so a similar climatological study should be possible for this location.
Acknowledgements. We gratefully acknowledge support for this research from Swedish Research Council (621-2010-3218). M. Mihalikova is supported by the Graduate School of Space Technology, Luleå University of Technology. MARA radar was financed by Knut and Alice Wallenberg's foundation and supported in its operation in Antarctica by Swedish Polar Research Secretariat (SWEDARP2010) and the Finnish Antarctic Research Programme (FINNARP2010).

Topical Editor P. M. Ruti thanks two anonymous referees for their help in evaluating this paper.

\section{References}

Baray, J.-L., Duflot, V., Posny, F., Cammas, J.-P., Thompson, A. M., Gabarrot, F., Bonne, J.-L., and Zeng, G.: One year ozonesonde measurements at Kerguelen Island $\left(49.2^{\circ} \mathrm{S}, 70.1^{\circ} \mathrm{E}\right)$ : Influence of stratosphere-to-troposphere exchange and long-range transport of biomass burning plumes, J. Geophys. Res., 117, D06305, doi:10.1029/2011JD016717, 2012.

Beuermann, J., Konopka, P., Brunner, D., Bujok, O., Günther, G., McKenna, D. S., Lelieveld, J., Müller, R., and Schiller, C.: Highresolution measurements and simulation of stratospheric and tropospheric intrusions in the vicinity of the polar jet stream, Geophys. Res. Lett., 29, 1577, doi:10.1029/2001GL014162, 2002.

Bourqui, M. S., Yamamoto, A., Tarasick, D., Moran, M. D., Beaudoin, L.-P., Beres, I., Davies, J., Elford, A., Hocking, W., Osman, M., and Wilkinson, R.: A new global real-time Lagrangian diagnostic system for stratosphere-troposphere exchange: evaluation during a balloon sonde campaign in eastern Canada, Atmos. Chem. Phys., 12, 2661-2679, doi:10.5194/acp-12-26612012, 2012.

Dibb, J. E., Talbot, R. W., Scheuer, E., Seid, G., DeBell, L., Lefer, B., and Ridley, B.: Stratospheric influence on the northern North American free troposphere during TOPSE: 7Be as a stratospheric tracer, J. Geophys. Res., 108, 8363, doi:10.1029/2001JD001347, 2003.

Dudhia, J.: Numerical study of convection observed during the winter monsoon experiment using a mesoscale two-dimensional model, J. Atmos. Sci., 46, 3077-3107, 1989.

Durran, D. R. and Klemp, J. B.: A compressible model for the simulation of moist mountain waves, Mon. Weather Rev., 111, 23412361, 1983.

Gettelman, A., Hoor, P., Pan, L. L., Randel, W. J., Hegglin, M. I., and Birner, T.: The Extratropical Upper Troposphere and Lower Stratosphere, Rev. Geophys., 49, RG3003, doi:10.1029/2011RG000355, 2011.

Helmig, D., Johnson, B., Oltmans, S.J., Neff, W., Eisele, F., and Davis, D.D.: Elevated ozone in the boundarylayer at South Pole, Atmos. Environ., 42, 2788-2803, doi:10.1016/j.atmosenv.2006.12.032, 2008.

Helsen, M. M., Van de Wal, R. S. W., and Van den Broeke, M. R.: The isotopic composition of present-day antarctic snow in a lagrangian atmospheric simulation*, J. Climate, 20, 739-756, doi:10.1175/JCLI4027.1, 2007.

Hocking, W. K., Carey-Smith, T., Tarasick, D. W., Argall, P. S., Strong, K., Rochon, Y., Zawadzki, I., and Taylor, P. A.: Detection of stratospheric ozone intrusions by wind profiler radars, Nature, 450, 281-284, doi:10.1038/nature06312, 2007. 
Holdsworth, D. A. and Reid, I. M.: A simple model of atmospheric radar backscatter: Description and application to the full correlation analysis of spaced antenna data, Radio Sci., 30, 1263-1280, doi:10.1029/95RS00645, 1995.

Holton, J. R.,Haynes, P. H.,McIntyre, M. E., Douglass, A. R., Rood, R. B., and Pfister, L.: Stratosphere-troposphere exchange, Rev. Geophys., 33, 403-439, doi:10.1029/95RG02097, 1995.

Hong, S.-Y., Dudhia, J., and Chen, S.-H.: A Revised Approach to Ice Microphysical Processes for the Bulk Parameterization of Clouds and Precipitation, Mon. Weather Rev., 132, 103-120, 2004.

Hong, S.-Y., Noh, Y., and Dudhia, J.: A new vertical diffusion package with an explicit treatment of entrainment processes, Mon. Weather Rev., 134, 2318-2341, 2006

Hooper, D. A., Arvelius, J., and Stebel, K.: Retrieval of atmospheric static stability from MST radar return signal power, Ann. Geophys., 22, 3781-3788, doi:10.5194/angeo-22-3781-2004, 2004.

Kirkwood, S., Wolf, I., Nilsson, H., Dalin, P., Mikhaylova, D., and Belova, E.: Polar mesosphere summer echoes at Wasa, Antarctica $\left(73^{\circ} \mathrm{S}\right)$ : First observations and comparison with $68^{\circ} \mathrm{N}$, Geophys. Res. Lett., 34, L15803, doi:10.1029/2007GL030516, 2007.

Kirkwood, S., Mihalikova, M., Rao, T. N., and Satheesan, K.: Turbulence associated with mountain waves over Northern Scandinavia - a case study using the ESRAD VHF radar and the WRF mesoscale model, Atmos. Chem. Phys., 10, 3583-3599, doi:10.5194/acp-10-3583-2010, 2010.

Lelieveld, J., and Dentener, F. J.: What controls tropospheric ozone?, J. Geophys. Res., 105, 3531-3551, doi:10.1029/1999JD901011, 2000.

Liu, H., Jezek, K., Li, B., and Zhao, Z.: Radarsat Antarctic Mapping Project digital elevation model version 2, Boulder, Colorado USA: National Snow and Ice Data Center, Digital media, 2001.

Mlawer, E. J., Taubman, S. J., Brown, P. D., Iacono, M. J., and Clough, S. A.: Radiative transfer for inhomogeneous atmosphere: RRTM, a validated correlated-k model for the long-wave, J. Geophys. Res., 102, 16663-16682, 1997.

Randriambelo, T., Barray, J. L., and Baldy, S.: The effect of biomass burning, convective venting and transport on tropospheric ozone over the indian ocean: Reunion island field observations, J. Geophys. Res., 105, 11813-11832, 2000.

Rao, T. N. and Kirkwood, S.: Characteristics of tropopause folds over Arctic latitudes, J. Geophys. Res., 110, D18102, doi:10.1029/2004JD005374, 2005.

Rao, T. N., Arvelius, J., and Kirkwood, S.: Climatology of tropopause folds over a European Arctic station (Esrange), J. Geophys. Res., 113, D00B03, doi:10.1029/2007JD009638, 2008.

Reid, H. J. and Vaughan, G.: Convective mixing in a tropopause fold, Q. J. Roy. Meteorol. Soc., 130, 1195-1212, doi:10.1256/qj.03.21, 2004
Semane, N., Peuch, V.-H., El Amraoui, L., Bencherif, H., Massarat, S., Cariolle, D., Attié, J.-L., and Abida, R.: An observed and analysed stratospheric ozone intrusion over the high Canadian Arctic UTLS region during the summer of 2003, Q. J. Roy. Meteorol. Soc., 133, 171-178. doi:10.1002/qj.141, 2007.

Shapiro, M. A.: Turbulent mixing within tropopause folds as a mechanism for the exchange of chemical constituents between the stratosphere and troposphere, J. Atmos. Sci., 37, 994-1004, doi:10.1175/1520-0469(1980)037<0994:TMWTFA>2.0.CO;2, 1980.

Skamarock, W. C. and Klemp, J. B.: A time-split nonhydrostatic atmospheric model for weather research and forecasting applications, J. Comp. Phys., 227, 3465-3485, 2008.

Sprenger, M. and Wernli, H.: A northern hemispheric climatology of cross-tropopause exchange for the ERA15 time period (19791993), J. Geophys. Res., 108, 8521, doi:10.1029/2002JD002636, 2003.

Sprenger, M., Croci Maspoli, M., and Wernli, H.: Tropopause folds and cross-tropopause exchange: A global investigation based upon ECMWF analyses for the time period March 2000 to February 2001, J. Geophys. Res., 108, 8518, doi:10.1029/2002JD002587, 2003.

Sprenger, M., Wernli, H., and Bourqui, M.: StratosphereTroposphere Exchange and Its Relation to Potential Vorticity Streamers and Cutoffs near the Extratropical Tropopause, J. Atmos. Sci., 64, 1587-1602, doi:10.1175/JAS3911.1, 2007.

Stohl, A.: Characteristics of atmospheric transport into the Arctic troposphere, J. Geophys. Res., 111, D11306, doi:10.1029/2005JD006888, 2006

Stohl, A. and Sodemann, H.: Characteristics of atmospheric transport into the Antarctic troposphere, J. Geophys. Res., 115, D02305, doi:10.1029/2009JD012536, 2010.

Sudo, K., and Akimoto, H.: Global source attribution of tropospheric ozone: Long-range transport from various source regions, J. Geophys. Res., 112, D12302, doi:10.1029/2006JD007992, 2007.

Tarasova, O. A., Brenninkmeijer, C. A. M., Jöckel, P., Zvyagintsev, A. M., and Kuznetsov, G. I.: A climatology of surface ozone in the extra tropics: cluster analysis of observations and model results, Atmos. Chem. Phys., 7, 6099-6117, doi:10.5194/acp-76099-2007, 2007.

Van Haver, P., De Muer, D., Beekmann, M., and Mancier, C.: Climatology of tropopause folds at midlatitudes, Geophys. Res. Lett., 23, 1033-1036, doi:10.1029/96GL00956, 1996.

Vaughan, G., Price, J. D., and Howells, A.: Transport into the troposphere in a tropopause fold, Q. J. Roy. Meteorol. Soc., 120, 1085-1103, doi:10.1002/qj.49712051814, 1994

Vaughan, G., Howells, A., and Price, J.: Use of MST radars to probe the mesoscale structure of the tropopause, Tellus A, 47, 5, doi:10.3402/tellusa.v47i5.11573, 1995. 